\title{
The Future of the Computing Curriculum: How the Computing Curriculum Instills Values and Subjectivity in Young People
}

\author{
Benjamin S Wohl \\ Sophie Beck \\ Lynne Blair \\ Lancaster University, Lancaster, UK
}

\section{DOI: $10.21585 /$ ijcses.v1i1.8}

\begin{abstract}
In these early stages of implementation of the English computing curriculum policy reforms, there are uncertainties with regards to the intentions of computing to young people. To date, research regarding the English computing curriculum has been mostly concerned with the content of the curriculum, its delivery and surrounding pedagogy. In contrast this paper seeks to explore the underlying motivation and values embedded in the computing curriculum. We propose that this curriculum has been driven by the needs of industry and the economy. We use Schwartz's values to examine how the teaching of computing has been primarily embedded within the value of selfenhancement. We conclude, that by looking at this context and the underlying value structure, we can reflect on the dramatic effects of the narrative and discourse around the content, delivery and purpose of teaching computing to young people. We propose the narratives of curriculum, influence pedagogy and this in turn, has a powerful impact on the young people's view of themselves and the world we want to equip them to create.
\end{abstract}

Keywords: computing curriculum, education research, subjectivity, computer science education, Schwartz's values.

\section{Introduction}

Since the early 1980s there has been a long, well documented, history of teaching computing and ICT in schools, and there has been a variety of justifications for this practice (Passey, 2015). This has ranged from early attempts to teach various levels of coding and algorithms using tools such as logo the turtle, to teaching general ICT skills such as word-processing and spread sheets. Most recently in 2014 the new National Curriculum Framework for England has introduced the new area of 'Computing' with the stated purpose of "A high-quality computing education equips pupils to use computational thinking and creativity to understand and change the world" (DfE, 2014, 217).

In this paper we pose the question: What is the underlying context and driver of teaching computing in schools and what are the values that these drivers imply? The values and context of the computing curriculum have the potential to make a profound difference to how pupils approach the subject of computing.

We start this paper by looking at three key influences on the context of the computing curriculum these are; the policy context, the academic discourse surrounding new forms of work and the digital economy. We then use Schwartz's basic human values to look at the value structures of the computing curriculum and how different values place the computing curriculum in one of two distinct narratives of education. We conclude by looking at how these narratives impact on pupils as they learning about computing.

Although much of current research surrounding the computing curriculum is related to delivery and content, there is a clear need for further research that examines the fundamental values, motivations and impacts of teaching computing to young people.

\section{Literature and Policy Context}

There are two fields which can be seen as attempting to describe the what the world of work will look like for pupils 
in the future. These broad areas are: first the attempts of a number of theorists (such as Peter Drucker and Alan Toffler) to envision the future of work, second the shift in the UK towards what is called the 'digital economy'. Even since early advances in computing there has been a recognition that digital technology would have a profound effect on the workplace. In the past 20 years a new kind of 'economy' has been identified which is reliant on digital technology. The digital economy (under its many guises such as the "new economy", "Knowledge economy" or "network economy") has been identified by UK policy makers as a major driver of economic growth (Innovate UK, 2015). There is appears to be an overt influence of this conception of the digital economy and digital economic policy on the computing curriculum. In this section we give a brief overview key influences on current English computing curriculum, briefly outlining the digital economy policy context, presenting an overview of digital economy literature, and the literature context surrounding 'new forms of work'.

\subsection{A New form of Work}

The industrial revolution created dramatic shifts in social, and therefore work patterns. By the 1950s, theorists began to reflect on the impact of these shifts and the impact these had on the nature of work, and the potential consequences of these changes. Drucker observed that due technological advancements of the industrial revolution, and the application of scientific management in the early 20th century, its concepts had become deeply entrenched in the specific notions of productivity in the workplace. Drucker proposed that workers would need a wider range of 'soft skills' to fully participate in work places of the future (Drucker, 1959, 67). As digital technology advanced further the futurist Alvin Toffler proposed other significant changes to the life and work of the individual citizen, proposing the 'electronic cottage' as the place where citizens of the future would both live and work (Toffler, 1980, 206).

A range of authors have continued on from Toffler and Drucker making predictions about new forms of work ranging from mass unemployment to employees being liberated from much of the dull, dreary and degrading aspects of employment (Nolan, 2002, 150; Ang and Parvi, 1994, 122; Methuen, 1980, 303). Looking back at the research that had taken place since the 1980s, when the information revolutions started to take effect, it seems that almost every potential form of work had been predicted at some point, these ranged from the profoundly utopia, such as Toffler's The Third Wave, to the deeply pessimistic (Baldry, 2011). The application of ICT to services had two significant consequences, firstly services became 'interactive' requiring more soft skills, and secondly services could be produced in place and consumed in another (ibid).

In fact, a number of theorists have proposed that having technical ICT skills alone are not enough have influence in the modern workplace (Rose, 2002, 167; Chillas, et.al., 2015, 4). A wide range of skills beyond just technical knowledge are important for success the future of world work: "English, project management and organisational skills, team working and communication skills, and both creativity and systematic ways of working" (Holtgrewe, 2014, 16).

\subsection{Digital Economy}

These findings are reflected in recent attempts to explore the 'digital economy'. As Drucker in the 1950s was describing how the skills of the industrial age were no longer appropriate, the development of the 'digital economy', can be classified as the emergence of "The Second Machine Age" (Brynjolfsson \& McAfee, 2014). In this second machine age there is an increased capacity of technology to take on a wider range of tasks both manual and intellectual. Will it be that, working in the 'digital economy' may have little to do with being able to 'use' technology but, rather, learning how to 'work with' robots and algorithms (Brynjolfsson \& McAfee, 2014, 94).

The danger of this new world of work in a digital economy is, that with a push for greater productivity, companies are able to employ fewer workers, a future that allows a few people to become very wealthy, and leading to the majority of workers being worse off (Keen, 2015, 61).

In terms of looking at the skills needed to generate value in this new economy, digital labour can range from highly creative tasks to projects where the person working may not even be aware of their contribution, such as conducting a web search (Fish \& Srinivasan, 2011). For example, the social web appears to be free, however there are both costs and benefits (Scholz, 2013,2). There is a price even for 'free' products and services on the internet and that 
instant is where digital labour exists, in the clicking of an accept box, in downloading of a file, in the completion of a search algorithm (Lanier 2014, 11).

If the claim is that the computing curriculum is preparing young people for the digital economy then we must first ask the questions presented by Scholz:

"What does it mean to be a digital worker today? The internet has become a simple-to-join, anyone-can-play system where the sites and practices of work and play increasingly wield people as a resource for economic amelioration by a handful of oligarchic owners" (Scholz, 2013, 1).

If the digital economy is 'simple-to-join' is there a need to teach pupils computing skills? Or is there more of a need to prepare young people for the new power dynamics and structures of being a digital worker? We are asking whether even if the purpose of the computing curriculum is overtly to prepare young people for a world of work and a digital future, the implicit purpose of the curriculum is far more about embedding a value system and subjectivity surrounding how young people relate to digital technology and the world of work.

\subsection{Policy Context}

The stated aim of the computing curriculum is to: "ensures that pupils become digitally literate - able to use, and express themselves and develop their ideas through, information and communication technology - at a level suitable for the future workplace and as active participants in a digital world" (Department of Education, 2014).

Implicit in this statement are preconceptions about what it means to be 'digitally literate', which "information and communication technology" are being referred to, what sort of "digital world" is being envision and what is meant by "active participation". By briefly exploring in this section the future of work and the digital economy we hope to develop a working conception of the context out of which the computing curriculum has emerged and the future it eludes to.

Specifically, the argument has been put forward that the purpose of teaching computing, as advanced in the curriculum itself, is to prepare young people for jobs of the future (Livingston \& Hope, 2015). This argument follows a prolonged discussion surrounded the effectiveness of the ICT curriculum to prepare young people for the modern workplace (Lgcplus.com, 2001, Lgcplus.com, 2002).

As the trajectory of education since the 1980's has increasingly become linked to industry, policy makers, further more emphasise that the UK needs a highly technical workforce, in order to "compete with their international counterparts for the best jobs and for the British workforce to have the right skills to compete in a global economy"("Maths and science must be the top priority in our schools, says Prime Minister - Press releases GOV.UK", 2014), and that merely being able to use ICT effectively will no longer be enough in the 21 st century. This comes alongside the recognition that the prior ICT curriculum had been inadequate in preparing young people for these jobs (Mitchell, 2013).

It seems that it was hoped that this reinvention of ICT as broader topic of computing would provide industry with a workforce that had the skills and problem solving abilities to drive the UK digital economy forward as well as digitally engaged members of society able to contribute to a digital world. As the Conservative government released their plans for a 'National College for Digital Skills' for world-beating digital and coding, this formed part of their “... long-term economic plan for Britain - making sure our children have the skills they need to thrive and get on. And by sticking to it, we will lift our children horizons and pull our country up in the world" "("Maths and science must be the top priority in our schools, says Prime Minister - Press releases - GOV.UK", 2014).

\section{Narratives and values of the England's Education System}

We consider that there is a single narrative that dominates England's computing curriculum. This is the narrative of education that emerged in 1988 with the establishment of the national curriculum and the centralisation of education policy in the UK, which has sought to use standardisation to create a "regime of state-controlled curricula, testing and assessment" (White, 2012, 506). Through this 'regime', increasingly, the purpose of education has come to be aligned to support social and economic progress (Shuayb and O' Donnell, 2008, 24). These reforms were brought in to with the ultimate goal to raise academic standards and enhance the employability skills of pupils to meet the coming economic needs of the country (ibid, 11). 
Economic growth has remained central to the National curriculum even as it has been reformed first by New Labour in 1999 with the emphasis on "skills for the economy" and again by the Conservative/Liberal democratic coalition in 2011. In 2010 the education secretary Michael Gove commissioned the Wolf Report (2011) which further linked the prioritisation of vocational education with economic growth.

This narrative has underpinned the coalition and conservative government's approach to education and aligns to a very specific set of skills, values and attitudes which are thought to be needed for the workplace. We have examined the educational roots of this dominant narrative, conducting an analysis of which values are implicit within the teaching of computing in education.

\subsection{Values underpinning the narratives}

We have applied Schwartz's (1992) theory of basic human values, to the narrative of education policy. Whilst many authors, and philosophers have offered their own perspective on what universal values are and their content, Schwartz's theory of basic human values offers an empirically tested model of universal values presented in a clear manner which illustrates the interrelationships between value types. Schwartz identifies ten motivationally distinct types of values that are most likely to be recognised across different cultures, these are: power, achievement, hedonism, stimulation, self-direction, universalism, benevolence, tradition, conformity and security (Schwartz and Boehnke, 2004, 231). Holmes et al. $(2012,17)$ discuss how the ten basic values types, consist of 58 specific values and are divided along two major axes, to produce four categories of high level value types.

1) Self- enhancement vs. Self-transcendence. These high level types of values represent individual pursuit of status and success (Holmes et al., 2012,17), compared to the concerns of 'bigger than self', which includes collective concerns of others and the environment and concern for 'self-development"' (Crompton, 2010,10).

2) Openness to change vs. Conservation. Openness to change includes stimulation, self-direction and some types of hedonism value types. Conservation values include those of security, maintaining tradition and conformity and order.

It is these four categories of high level value types that will form to form themes of the narratives told by the National Curriculum in England (2014), computing curriculum and the wider discourses of the UK's education system.

\subsection{Self Enhancement narrative of the computing curriculum}

In 2011 the Framework for the National Curriculum, A report by the Expert Panel for the National Curriculum was published by the Department for Education. The report recommended that:

"Information and communication technology is reclassified as part of the Basic Curriculum and requirements should be established so that it permeates all National Curriculum subjects. We have also noted the arguments, made by some respondents to the Call for Evidence,that there should be more widespread teaching of computer science in secondary schools. We recommend that this proposition is properly considered" (DfE, 2011,24).

As the computing curriculum has been shaped by the wider discourses around the 'digital economy', and the need for increasing the Science, Technology, Engineering and Mathematic (STEM) 'pipeline' in education. This 'pipeline' has been, and still does remain a concern in the wider social and political context. In 2014 David Cameron, stated he wanted to "ensure future generations are able to compete with their international counterparts for the best jobs for the British Workforce to have the right skills to compete in a global economy" ("GOVERNMENT'S ICT INITIATIVE CONTINUES TO PLAY IMPORTANT ROLE, SAYS SECOND OFSTED REPORT.", 2002). Statements such as this communicate self enhancement values such as; wealth, success, ambition, capability, intelligence, power. These values implicitly strengthen the narrative as computing curriculum as key to promoting self- enhancement values. Narratives and values have recently become an area of interest in studies that explore concerns over the feeding STEM 'pipeline', O'Neil et.al. $(2014,150)$ highlights that "Due to the wider framing of education, narratives around STEM tend to default to individualism, success and wealth rather than a collective concern".

However, the role of inclusive values, or the incorporation of self-transcendent values into STEM subjects, is appearing to recognised from a number of studies. Goldweber et.al. $(2013,59)$ explore computer science $(\mathrm{CS})$ in the 
context of social good. By teaching CS in the context of education it seeks to "convey and reinforce computing's social relevance and potential for positive social impact". Their discussion gives a compelling argument on how learning the technical skills of CS can be greatly enhanced by contextualised learning in the domain of selftranscendent values. What we think this demonstrates the contradiction between the policy context which is underpinned by a desire to deliver self-empowerment value through the computing against broader social desire to have self-transcendent values embedded into area of computer science. What is clear is that values are only being taught implicitly and are explicitly neglected from the STEM context (Kopp et al. 2016).

\subsection{Changing the narrative of the computing curriculum}

The computing curriculum has been built upon the premise of development of skills for instrumental purposes. Fitting the wider dominant narrative of skills for economy whereby the curriculum develops tools needed to succeed and as an individual in an increasingly digital world. If we view the computing curriculum as a system, we can take the overarching narratives of education and create two definitions of what kind of education system the computing curriculum is for.

These two narratives are:

1) Computing curriculum is a system for developing capability and intelligence for personal self enhancement to support an individualist society. This accumulates into the world view that education is a means to an end, a means to develop individual skills for financial gain and success, that within itself contributes and perpetuates to the self enhancement of the wider social and political context.

Or

2) The computing curriculum is a system to empower individuals to develop capability and intelligence for selftranscendent values to support a collective society. This could accumulate into a world view that education is an ends within itself, a means to enjoy learning for learning's sake of self-development and to and develop individual capability that supports collective prosperity.

We feel that the first narrative represents the overall direction of the broader national curriculum, which is encouraging pupils to prepare to use computing skills in a future world dominated by the digital economy. Although there is some evidence that the second narrative is gaining increasing attention, there is little indication that this second narrative will become the main driver of computing education in school. Considering the dominant narrative of the computing curriculum we will next consider how this may be internalised by pupils.

\section{How to think like a computer scientist}

We propose that having understood the context, values and narratives of the computing curriculum it is worth considering the potential affect on the pupils subjected to this curriculum. In this section we will look at how pupils are shaped in to subjects who think 'like a computer scientist" through engagement with the computing curriculum. Although there is a wide range of 'subjectivities' and affects of this curriculum we feel that in light of the values, and narratives resulting from these values, the overt subjectivity that is produced is one of rationality and economic self enhancement.

To consider how pupils are shaped into subjects through the curriculum we are drawing on Foucault's conception of subjectivity as set out in Discipline and Punishment (1995), which proposes that the subject is formed out of a power relationship, which through governmentality controls the types of subjectivities that are available to the individual (Foucault, 1995, 785).

We question the assumed purpose of introducing a more comprehensive curriculum on computing, and also the effect of the content of that curriculum as it is within the interaction of the content and the purpose of content that we see a power based relationship with the pupils engaged in learning. It is in this intersection where the pupils builds a relationship with the topic and develops a sense of subjectivity, in relationship to that topic.

What kind of subjectivity is shaped by the narratives of the computing curriculum?

This relationship is reflected in the term "Computational Thinking". Computational thinking is seen as a key skill for a world where working with computers will be essential, and should be integrated in the classroom from an early age (Wing, 2008). Computational thinking is not strictly 'thinking like a computer' but is a process of problem 
solving which mirrors the steps that a computer (or a computer scientist) might take. Computational thinking should be seen as including the following concepts: algorithms, logical reasoning, decomposition of complex problems, identifying and using patterns, using abstraction to solve problems (Berry, 2014).

When implemented it encourages pupils to approach problems in a very specific way, and see the most efficient (if not the only) way of solving problems as the application of computational logic. This in contrast Resnick (2012) who sees the potential in teaching computing and computational thinking as a way to deliver creativity and collaboration. The tight definition of how the curriculum as it is currently presented and delivered is rooted in teaching specific skills, the computing curriculum has become a place for reproducing and defining a social self, for transmitting an aspect of the social and defining a context for subjectivity.

\subsection{The Subjectivity of the Computing Curriculum}

In these contrasting approaches the to computational thinking we see again the dualism of the self-enhancement values in contrast to self-transcendent values. The context of the of the computing curriculum in England means that the approach to computational thinking which focuses on logic is seen as useful for the emerging digital economy while the creative approach is being sidelined.

The subjectivity of the pupils is shaped by this power structure, which frames computing and computational thinking as a 'rational' approach to the world which will help them 'advance' in a work context. Pupils are guided directly toward the context of the digital economy. Computing for the pupils rather than being a general inclusive skill, is specifically framed to be a skill for the digital economy.

To understand the effect of education on subjectivity we first point to the work of Paul Willis in 1977, who observed how the education process was even at that point prioritising a degree of individualism, and certain kind of work ethic. He saw how in school it was "common practice of use the threat of the future [work] and the competitiveness of the world of work to drive a wedge into the solidarity of the group" (Willis, 1981, 164). This is similar to how the conception of the digital economy and the threat of being 'left behind' in the digital age is being used in the current computing and STEM education to prioritise a learning of computing skill in order to be prepared for the new world of work.

The subtext and narrative of the computing curriculum is one of a highly technical, rational subject working primarily for self-enhancement goals in a covert shaping of subjectivity. It is our contention that the computing curriculum has been redesigned to reflect the new realities and the need for the highly skilled flexible workers who possess requisite technical skills in management, information handling, communication, problem solving, and decision making (Peters, 2009, 66-67). This image of the future worker has these specific skills framed within terms of economics, self enhancement, and a computational logic.

\section{Conclusion and Recommendations}

In this paper we have sought to examine the underlying purpose of the computing curriculum by looking at the context it has be developed out of, looking at the values which are present within in and be revealing the narrative of education which it fits within. We feel that given these factors pupils are being shaped to approach computing from a specific perspective.

In conclusion, we feel there is room for significant further empirical and theoretical research that goes beyond purely examining the content and delivery of computing in schools but takes a deeper look at the context and values that are instilled within that content and delivery. Currently, there seems to be little examination of the values embedded within the computing curriculum and this has meant that the main drivers of teaching computing and computer science have been centred around the policy motivations of preparing young people for new world of work in the digital economy.

Although there is a strong argument that pupils will need these skills to engage in the digital economy, these are not the only skills they will need for the digital economy nor is this the sole use of computing skills. By so rigidly defining the power structure within which pupils learn about computing, as their subjectivity is shaped these other possibilities are closed down. 
We feel it is essential that the discourse of computing education in schools is seen to include these more fundamental questions in regards to teaching computing in school, and how the subjectivity that the curriculum imposes, can in turn, influence the way children learn computing in order to 'change the world'. What we really need to be asking is what sort of world are we influencing them to create?

\section{References}

Baldry, C. (2011). Editorial: chronicling the information revolution. New Technology, Work And Employment,26(3), 175-182. http://dx.doi.org/10.1111/j.1468-005x.2011.00267.x

Berry, M. (2016). Computational Thinking in Primary Schools. Milesberry.net. Retrieved 1 October 2016, from http://milesberry.net/2014/03/computational-thinking-in-primary-schools/

Brynjolfsson, E. \& McAfee, A. (2014). The second machine age. New York: W. W. Norton \& Company, Inc.

Chillas, S., Marks, A., \& Galloway, L. (2015). Learning to labour: an evaluation of internships and employability in the ICT sector. New Technology, Work And Employment, 30(1), 1-15. http://dx.doi.org/10.1111/ntwe.12041

Crompton, T. (2010). Common Cause The Case for Working with our Cultural Values. Woking: WWF-UK. Retrieved from http://assets.wwf.org.uk/downloads/common_cause_report.pdf

Department of Education,. (2014). National Curriculum in England Key Stage 3 and 4 Framework Document (pp. 85 - 87). London: Department of Education.

Drucker, P. (1959). Landmarks of tomorrow. New York: Harper.

Eyre, M. (1980). Barrie Sherman: Employment will fall.Electronics And Power, 26(4), 303. http://dx.doi.org/10.1049/ep.1980.0180

Fish, A. \& Srinivasan, R. (2011). Digital labor is the new killer app. New Media \& Society, 14(1), 137-152. http://dx.doi.org/10.1177/1461444811412159

Flanagan, M., Howe, D., \& Nissenbaum, H. (2008). Flanagan, M. Howe, D. and Nissenbaum, H. (2008) Embodying Values in Technology, Information Technology and Moral Philosophy. In J. Van Den Hoven \& J. Weckert, Information Technology and Moral Philosophy (1st ed., pp. 322- 353). Cambridge: Cambridge University Press. Retrieved from https://www.nyu.edu/projects/nissenbaum/papers/embodying_values.pdf

Foucault, M. (1995). Discipline and punish. New York: Vintage Books.

FULL IMPACT OF GOVERNMENT'S ICT INITIATIVES YET TO BE ACHIEVED, SAYS OFSTED REPORT. (2001). lgcplus.com. Retrieved 27 September 2015, from http://FULL IMPACT OF GOVERNMENT'S ICT INITIATIVES YET TO BE ACHIEVED, SAYS OFSTED REPORT

Goldweber, M., Barr, J., Clear, T., Davoli, R., Mann, S., Patitsas, E., \& Portnoff, S. (2013). A framework for enhancing the social good in computing education.ACM Inroads, 4(1), 58. http://dx.doi.org/10.1145/2432596.2432616

GOVERNMENT'S ICT INITIATIVE CONTINUES TO PLAY IMPORTANT ROLE, SAYS SECOND OFSTED REPORT.. (2002). lgcplus.com. Retrieved 27 September 2015, from http://www.lgcplus.com/governments-ictinitiative-continues-to-play-important-role-says-second-ofsted-report/1302528.article

Holmes, T. (2011). The common cause handbook. Machynlleth: Public Interest Research Centre Ltd.

Holtgrewe, U. (2014). New new technologies: the future and the present of work in information and communication technology. New Technology, Work And Employment, 29(1), 9-24. http://dx.doi.org/10.1111/ntwe.12025

House of Commons Children, Schools and Families Commitee,. (2009). National Curriculum Fourth Report of session 2008-09. London: House of Commons.

Innovate UK,. (2015). Digital economy strategy 2015 - 2018. Swindon: North Star House.

J. Ang, \& F. Pavri,. (1994). A survey and critique of the impacts of information technology. International Journal Of Information Management, 14(2), 122-133. http://dx.doi.org/10.1016/0268-4012(94)90031-0 
James, P. (2009). Blurring the boundaries-STEM education and education for sustainable development. Design And Technology Education: An International Journal,14(1), 37 - 48.

Johnson, M. (2007). Subject to change. London: ATL.

Keen, A. (2015). The Internet is not the Answer (p. Kindle edition). London: Atlantic Books.

Kopp, B., Mandi, H., \& Niedermeier, S. (2016). EVALUATING THE INTEGRATION OF VALUES IN STEM EDUCATION. In 10th International Technology, Education and Development Conference(pp. 8362-8366). Valencia: IATED. Retrieved from https://library.iated.org/publications/INTED2016

Lanier, J. (2013). Who owns the future? Milton Keynes: Penguin Books.

Livingston, I. \& Hope, A. (2015). Next Gen. Transforming the UK into the world's leading talent hub for the video games and visual effects industries. London: Nesta. Retrieved from https://www.nesta.org.uk/sites/default/files/next_gen_wv.pdf

Maths and science must be the top priority in our schools, says Prime Minister - Press releases - GOV.UK. (2014). Gov.uk. Retrieved 2 October 2016, from https://www.gov.uk/government/news/maths-and-science-must-bethe-top-priority-in-our-schools-says-prime-minister

Mitchell, B. (2013). Computing in Schools. ITNOW, 55(2), 44-45. http://dx.doi.org/http://dx.doi.org/10.1093/itnow/bwt020

Nolan, P. (2002). The ESRC Future of Work Programme.New Tech Work Empl, 17(3), 150-151. http://dx.doi.org/10.1111/1468-005x.00100

O'Neil, M., Haydon, A., \& Simon, A. (2014). Narrative Holes in STEM Storytelling: A Field Frame Analysis. Washington D.C.: Frame Works Institute. Retrieved from http://www.frameworksinstitute.org/assets/files/PDF_STEM/STEMFFANarrativeHolesFinal.pdf

Passey, D. (2015). Computer science (CS) or information and communication technologies (ICT) : curriculum decisions or curriculum concerns?. Dimensio, 3, 45-50.

Peters, M. (2009). Education, Enterprise Culture and the Entrepreneurial Self: A Foucauldian Perspective. He $\begin{array}{llll}\text { Journal Of } & \text { Educational 6nquiry, }\end{array}$ http://dx.doi.org/http://www.ojs.unisa.edu.au/index.php/EDEQ/article/view/558/428

Prime, G. (1993). Values in technology: Approaches to learning. Design \& Technology Teaching, 26(1), 30 - 36.

Resnick, M. (2012). Sowing the Seeds for a More Creative Society. Learning $\backslash \&$ Leading With Technology, 35(4), $18-22$.

Rose, M. (2002). IT professionals and organisational ascendancy: theory and empirical critique. New Tech Work Empl, 17(3), 154-169. http://dx.doi.org/10.1111/1468-005x.00102

Scholz, T. (2013). Digital labor. New York: Routledge.

Schwartz, S. \& Boehnke, K. (2004). Evaluating the structure of human values with confirmatory factor analysis. Journal Of Research In Personality, 38(3), 230-255. http://dx.doi.org/10.1016/s0092-6566(03)00069-2

Shuayb, M. \& O'Donnell, S. (2008). Aims and values in primary education. Cambridge: Primary Review, University of Cambridge Faculty of Education.

St.Pierre, E. (2006). Scientifically Based Research in Education: Epistemology and Ethics. Adult Education Quarterly, 56(4), 239-266. http://dx.doi.org/10.1177/0741713606289025

Straw, S. \& Macleod, S. (2013). Improving young people's engagement with science, technology, engineering and mathematics (STEM). Slough: National Foundation for Educational Research. Retrieved from https://www.nfer.ac.uk/publications/99927/99927.pdf

Toffler, A. (1980). The third wave. New York: Morrow.

White, J. (2007). What schools are for and why. Impact,2007(14), vi-51. http://dx.doi.org/10.1111/j.2048416x.2007.tb00116.x

White, J. (2012). Towards A Compulsory Curriculum (RLE Edu B). Hoboken: Taylor \& Francis.

White, S. (1992). Universals in the Content and Structure of Values: Theoretical advance and empirical tests in 20 
countries. Advances In Experimental Social Psychology 25, 25, 1-65.

Williams, J. (2011). STEM education: Proceed with caution. Design And Technology Education: An International Journal, 16(1).

Willis, P. (1981). Learning to labor. New York: Columbia University Press.

Wing, J. (2008). Computational thinking and thinking about computing. Philosophical Transactions Of The Royal Society A: Mathematical, Physical And Engineering Sciences, 366(1881), 3717-3725. http://dx.doi.org/10.1098/rsta.2008.0118

Wolf, A. (2011). Review of Vocational Education - The Wolf Report. London: Gov.uk. 